\title{
OBSERVATIONS ON THE ACIDOPHIL CELLS OF THE ADENOHYPOPHYSIS IN PREGNANT AND LACTATING RABBITS
}

\author{
M. ALLANSON, E. CAMERON AND C. L. FOSTER \\ Department of Biology, St Mary's Hospital Medical School, London
}

(Received 31st January 1966)

\begin{abstract}
Summary. Two varieties of acidophil cells, one staining with erythrosine and the other with orange $G$, were observed in the adenohypophysis of the rabbit. Granular erythrosinophil cells were plentiful only near the postero-ventral and lateral surfaces of the gland in non-parous animals and in early pregnancy: after mid-pregnancy they increased in numbers greatly and spread throughout the pars distalis proper. There was rapid and widespread degranulation of the erythrosinophils within $24 \mathrm{hr}$ of parturition and during the first 2 weeks of lactation. The number of granular stages rose and of degranulated stages fell, in the 3rd and 4th weeks post partum. The yellow cells showed similar but less striking changes in numbers and secretory activity during pregnancy and lactation.

It is suggested that prolactin is produced by the erythrosinophil cells.

One or more globular intra-nuclear bodies appear to be a characteristic of the erythrosinophil cells in some stages of the secretory cycle; such inclusions were not noted in the nuclei of the yellow acidophils or of the mucoid cells.
\end{abstract}

\section{INTRODUCTION}

During the last 10 years, evidence that prolactin and growth hormone are produced by separate varieties of acidophil cells, which can be differentiated by appropriate staining methods, has come from studies on the hypophyses of a wide variety of mammals, e.g. the bat, cat, guinea-pig, rat, mole, sheep and pig. The existence of a third variety of acidophil, producing adrenocorticotrophin, has been reported in a few species. Prolactin cells have been recognized by their hyperplasia, hypertrophy and appearance of intense secretory activity in glands known to have a high prolactin content, i.e. from pregnant and lactating animals, from reserpine-treated rats and in hypophysial grafts (Bugnon, 1963; Pasteels, 1963; Racadot, 1963; Herlant, 1964, 1965).

Earlier accounts of the acidophil cells of the rabbit hypophysis have been based on material fixed in formal-sublimate and stained by Heidenhain's azan method (Friedgood \& Dawson, 1938; Pearse, 1951, 1952; Gepts, 1954), so it is difficult to equate the cell types described with those found in other species by 
means of different techniques. Friedgood \& Dawson (1938) demonstrated two acidophil types in the female rabbit, one staining with carmine and the other with orange $G$. They noted hyperplasia and increased secretory activity of the carmine cells in the $3 \mathrm{hr}$ following coitus and again late in pregnancy and suggested that these cells produced a gonadotrophic hormone. Dawson (1946) later identified the carmine cell of the cat with the secretion of prolactin. Pearse (1951, 1952) and Foster (1963) concluded that the mucoid cells were more active than the acidophils shortly after coitus and were the more probable source of gonadotrophic hormones. Gepts (1954) studied the gland of the lactating rabbit and found widespread secretory activity of both carmine- and orangestained acidophils. He was not convinced that the carminophils represented a separate cell category and suggested that they were the storage phase in the secretory cycle of a single acidophil type. Both Dawson (1946) and Gepts (1954) pointed out that azocarmine is not a satisfactory selective stain and that it was often impossible to determine whether a cell was carminophil or orangeophil.

Herlant maintains that azocarmine reacts with both the LH-cells and the acidophil cells in some species (see Herlant, 1964, 1965). Hence there is uncertainty whether, in the rabbit, carmine stains both prolactin cells and LH-cells, prolactin cells alone, or the storage phase in a single acidophil cell type. It appeared to be useful, therefore, to examine the hypophyses of pregnant and lactating rabbits using staining methods found reliable for the differentiation of prolactin and growth hormone cells in other mammalian species.

\section{MATERIALS AND METHODS}

Thirty-nine mature young rabbits of the Dutch strain weighing approximately 2 to $2 \frac{1}{2} \mathrm{~kg}$ were used. Five does served as unmated controls; thirteen were killed at various times during pregnancy, eighteen during lactation and one at 2 days after the cessation of nursing (see Table 1). The hypophyses of two males were also examined. None of the females had previously bred, excepting one killed at 22 days post partum.

TABle 1

ANIMALS USED

\begin{tabular}{l|l|c}
\hline \multicolumn{1}{|c|}{ Condition } & $\begin{array}{c}\text { No. of } \\
\text { animals }\end{array}$ \\
\hline Controls & Unmated mature virgin does & 5 \\
& Mature bucks & 2 \\
Pregnancy & 4th to 7th days & 5 \\
& 11th to 14th days & 2 \\
& 15th to 21st days & 2 \\
24th to 28th days & 4 \\
& 15t to 7th day post partum & 5 \\
& 9th to 13th day post partum & 5 \\
Post-lactation & 15th to 19th day post partum & 4 \\
Total & 22nd to 31st day post partum & 1 \\
& 2 days after weaning, 34 days post partum & 39 \\
\hline
\end{tabular}


The pituitaries were fixed by perfusion in Baker's formal-calcium-cadmium fluid as described by Allanson, Foster \& Menzies (1957, 1959) but an electrically driven pump was used for better control of the perfusion procedure.

Paraffin sections at $5 \mu$ were cut serially in the horizontal plane. In seven animals, twenty adjacent sections were cut at $2.5 \mu$ and mounted separately for study of the nuclei.

Several staining methods, including Herlant's tetrachrome (1960), were tested. It was found that Gleveland \& Wolfe's trichrome stain (1932) could be modified to give good results after the fixative used. Difficulty was experienced at first in retaining the erythrosine stain during the subsequent passage through an aqueous solution of orange $\mathrm{G}$. This was overcome by lengthening the time in the erythrosine bath, and by using an alcoholic solution of orange G. Light green was chosen for staining the mucoid cells instead of the aniline blue of the original formula since it enhanced the contrast between the orange-red and yellow colours of the acidophil cells, and did not stain the nuclei. The staining solutions must be fresh and are rarely effective if more than 3 to 5 days old.

\section{Staining method}

(1) Bring sections to water. Stain nuclei lightly with celestin blue 2 to $3 \mathrm{~min}$ and then with Mayer's haemalum 2 to $3 \mathrm{~min}$.

(2) Wash in running tap-water $15 \mathrm{~min}$.

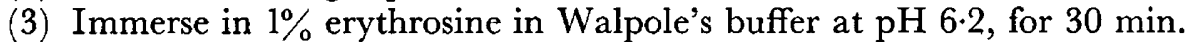

(4) Transfer, without rinsing, to $0.5 \%$ orange $\mathrm{G}$ in $95 \%$ alcohol containing $2 \%$ of phosphotungstic acid and leave for $5 \mathrm{~min}$.

(5) Transfer to $1 \%$ phosphotungstic acid for $3 \mathrm{~min}$.

(6) Stain with $1.5 \%$ light green in $1.5 \%$ acetic acid, brought to $\mathrm{pH} 4.0$ with sodium bicarbonate, for $5 \mathrm{~min}$.

(7) Differentiate in distilled water to remove excess of light green 1 to $2 \mathrm{~min}$.

(8) Blot with filter paper, dip in absolute alcohol-xylol mixture (1:3), clear in xylene.

A representative series of sections from each hypophysis, regularly spaced from dorsal to ventral surface, was stained by the modified Cleveland-Wolfe method; a similar series was treated with PAS-orange G for the identification of mucoid cells, and another series with pyronine-methyl green for the demonstration of RNA. The Feulgen reaction for DNA was used on several slides.

To test whether any mucoid cells reacted with erythrosine, all the cells in several fields of a trichrome-stained preparation were drawn with the aid of a camera lucida and the same cells identified after decolorization and re-staining of the section with PAS-orange G. The cell types rich in RNA were identified by a similar procedure in sections treated first with pyronine-methyl green and later with the trichrome stain.

Acidophil cells

\section{RESULTS}

Two kinds of acidophil cells could be distinguished in all the hypophyses examined. Both kinds were PAs-negative.

(1) Yellow cells. Typically oval cells containing fine cytoplasmic granules 
stained a bright, clear yellow in Cleveland-Wolfe preparations. The nucleus was frequently elongated and somewhat irregular in outline, but rounded forms were also encountered (Pl. 1, Figs. 1 to 4).

(2) Erythrosinophil cells. Larger cells, usually polygonal in shape, containing coarse cytoplasmic granules staining deep orange or red in Cleveland-Wolfe preparations. The nucleus was typically round and vesicular; it sometimes contained one or more globular, erythrosinophil inclusions which might occupy most of the nuclear area (Pl. 1, Figs. 1 to 4 ).

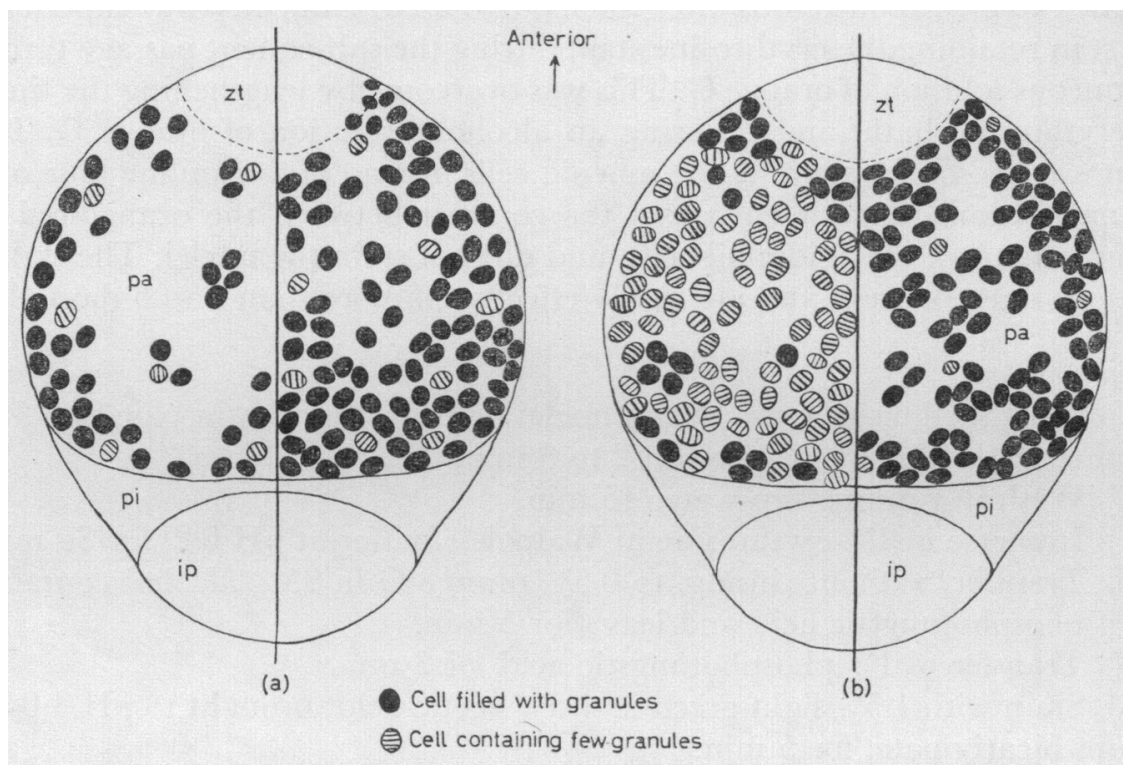

TEXT-FIG. 1. (a) Diagrammatic representation of a horizontal section through the adenohypophysis of a female rabbit. The left-hand side represents the distribution of erythrosinophil cells in a mature, non-parous animal, the right-hand side that in an animal in the 4th week of pregnancy.

(b) Similar to (a). The left-hand side represents the distribution of erythrosinophil cells in the 1st week of lactation, the right-hand side that in the 4th week of lactation.

ip, Infundibular process; pi, pars intermedia; pa, pars distalis proper; zt, zona tuberalis.

The yellow acidophils were the dominant cell type in the pars distalis of the mature virgin does; they were plentiful everywhere except in the zona tuberalis. Groups of the erythrosinophil cells were concentrated on the postero-ventral and lateral surfaces and also near the junction of the pars distalis and pars intermedia; small clusters were scattered in the central region of the gland (Text-fig. la). The erythrosinophils rarely extended into the dorsal half of the hypophysis. The yellow cells included both lightly and heavily granulated forms. Most of the erythrosinophils were large and filled with granules (Pl. 1, Fig. 1). In the two male hypophyses examined, the clumps of erythrosinophils were smaller and more widely dispersed than in the females.

The relative numbers of yellow cells and erythrosinophils appeared little changed during the first half of pregnancy. In the second half, however, there was a striking and progressive increase in the number of granular erythrosinophils. They spread to all parts of the pars distalis proper until, just before 

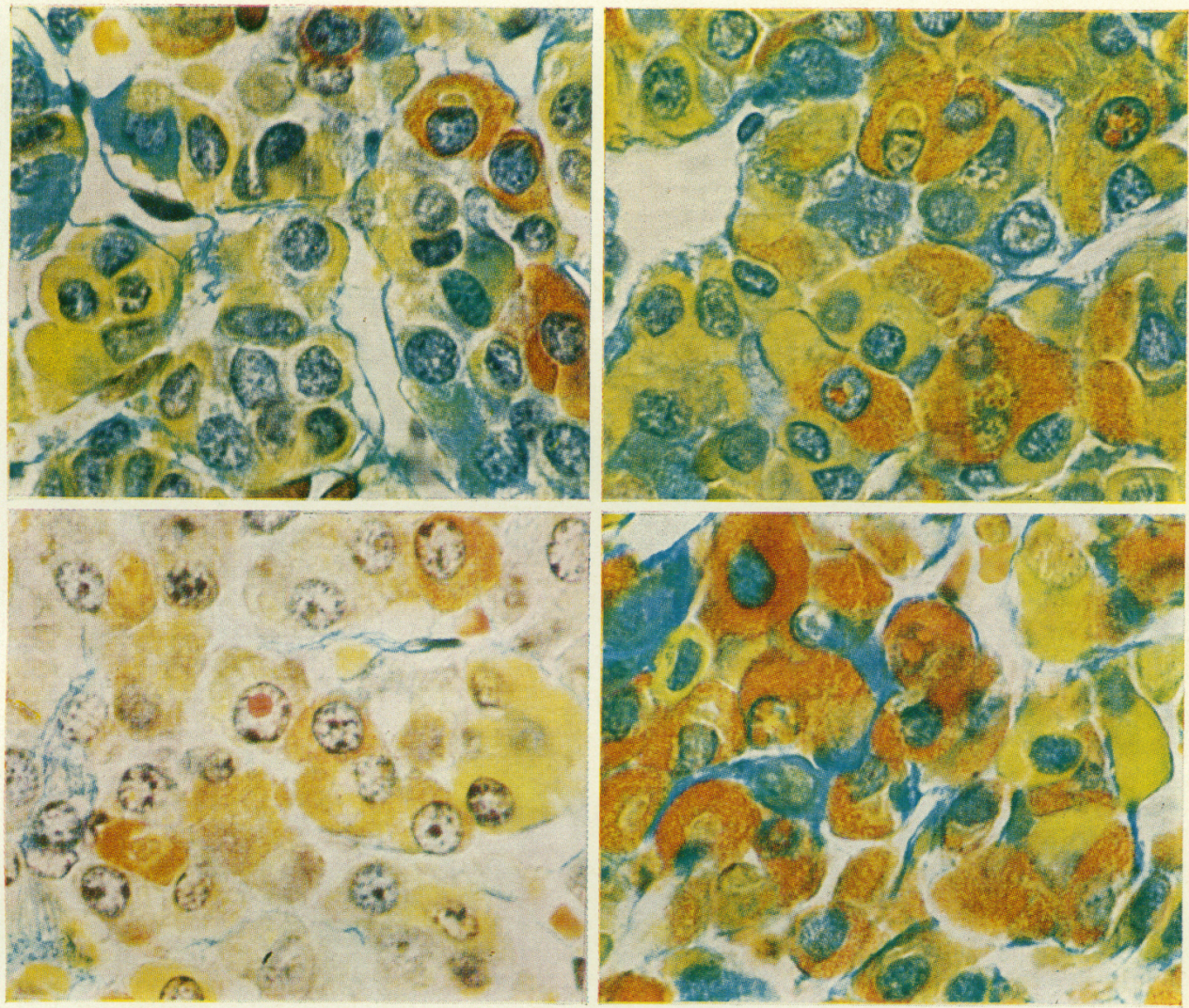

All sections were stained with the Clcveland-Wolfe trichrome stain. $\times 920$ approx.

Fig. 1. Pars distalis of mature, non-parous female rabbit showing two types of acidophil cells: coarse-granuled erythrosinophil cells and fine-granuled yellow cells. Some of the yellow cells are lightly granulated. Mucoid cells are bluish green.

lig. 2. Pars distalis of rabbit on 26th day of pregnancy. Both types of acidophils are well filled with granules. The erythyrosinophil cells are more numerous than in Fig. 1 ; intranuclear bodies can be seen in two of them, a single one towards the lower left and a multiple one towards the upper right of the field.

Fig. 3. Pars distalis of rabbit on 10th day of lactation showing lightly granulated erythrosinophil and yellow cells. Intra-nuclear body in degranulated cell in centre of the field.

FIG. 4. Pars distalis of rabbit 2 days after cessation of suckling ( 34 days post partum), showing heavily granulated erythrosine and yellow cells. Intra-nuclear bodies are present in an erythrosinophil cell at left of centre.

(Facing p. 322) 
parturition, they equalled or even exceeded the yellow cells in number in all areas (Text-fig. 1a; Pl. 1, Fig. 2). After mid-pregnancy there was a moderate increase in the proportion of RNA-rich cells among both varieties of acidophil cells.

There was a striking change in the condition of the erythrosinophils on the commencement of lactation. By $24 \mathrm{hr}$ post partum, granule-filled forms were extremely scarce and pale, lightly-granulated forms occupied extensive areas throughout the pars distalis. Most of these pale cells showed signs of intense secretory activity; the nucleus, nucleoli and Golgi zone were hypertrophied; the cytoplasm contained dense masses of RNA and vacuolization of the cell periphery suggested rapid extrusion of secretory material (Text-fig. 1b). Large, granular stages predominated among the yellow cells, but the high proportion of cells rich in RNA and showing varying degrees of granular loss indicated that these cells also were very active.

The histological structure was similar in all animals examined during the 1st and 2nd weeks of lactation (Pl. 1, Fig. 3), but the relative extent of the areas of granular and pale cells varied from individual to individual. Different intervals of time between death and the previous nursing period may account for some of this variation. To test this hypothesis, glands were examined from two animals killed at 14 days and two at 19 days post partum. Both pairs had been separated from their young for $10 \mathrm{hr}$; one of each pair was killed at the end of this period, the other after suckling her litter for $30 \mathrm{~min}$. Granular erythrosinophils were more numerous in the females killed after the 10-hr separation than in those allowed to nurse their young, although the contrast between the glands did not appear to be as striking as that observed in lactating rats after similar treatment at 6 days post partum (Pasteels \& Herlant, 1962).

During the 3rd and 4th weeks of lactation there was a steep rise in the number of granular erythrosinophils and yellow cells, with a corresponding fall in the number of pale, lightly-granulated stages (Text-fig. 1b). In the animal examined at 2 days after cessation of suckling (34 days post partum) there were few areas of degranulating cells and the number of granular cells, both yellow and erythrosinophil, approached that seen at the end of pregnancy (Pl. 1, Fig. 4).

\section{The intra-nuclear bodies}

The intra-nuclear bodies appeared to be a characteristic of the erythrosinophil cells; none were found in the yellow acidophils or in mucoid cells. They occurred in both sparsely and densely granular erythrosinophils, and also in cells empty of granules (Pl. 1, Figs. 2 and 3). The latter were presumed to be degranulated stages of the erythrosinophils.

The nuclear inclusions stained intensely with erythrosine in Cleveland-Wolfe preparations. After the PAs/orange $G$ technique they stained with orange $G$ and so did not contain glycogen. They did not appear to contain RNA or DNA as they remained uncoloured in pyronine-methyl green preparations in contrast to the bright red of the nucleoli, and they were Feulgen-negative. A preliminary electron microscopic study has shown that the intra-nuclear bodies are membrane-bound and contain smaller particles which resemble the secretion granules in the cytoplasm (Foster, Young, Allanson \& Cameron, 
1965). A granular structure could be discerned with the optical microscope in exceptionally favourable circumstances.

Nuclear inclusions were found in all the thirty-nine glands studied, with the exception of three of the control females and three of the early pregnancy stages. In each of the remaining thirty-three animals, 500 to 600 cells were examined and the inclusions counted. Intra-nuclear bodies were present in $0.5 \%$ of erythrosinophil cells in the control females and in the male animals, and in $0.8 \%$ to $6.9 \%$ in the pregnant animals, the higher figures being from late pregnancy stages. In the lactating animals, the figure ranged from $2.8 \%$ to $10.9 \%$ in the first 3 weeks post partum, and fell to $0.7 \%$ to $1.6 \%$ in animals killed from 22 to 34 days post partum. The count was restricted to cells containing granules, i.e. to cells which could be identified with confidence. Figures somewhat higher than those given above would have been obtained in the early lactational stages if non-granular cells had been included.

\section{DISCUSSION}

Two varieties of acidophil cells can be demonstrated in the hypophysis of the rabbit; they differ in morphological characters, in staining affinities, and in their behaviour during pregnancy and lactation. It appears improbable that, as Gepts (1954) suggested, the cells with coarse granules are merely a storage phase in the secretory cycle of a single acidophil cell type since all gradations from lightly to heavily granulated forms of both erythrosinophil and yellow cells can be found in the same area of the pars distalis, often in the same microscopic field (Pl. 1, Figs. 1 to 4). The two varieties both exhibit great activity during pregnancy and lactation, but the massive build-up in numbers of the erythrosinophil cells before parturition, and the signs of intense secretory activity in them during lactation, are more remarkable than the concurrent changes in the yellow cells. It is significant that these signs of heightened activity in the erythrosinophil cells occur when the content of prolactin is above normal. Meites \& Turner (1942) reported that the level of prolactin in the hypophysis of the rabbit rose slowly in the 4th week of pregnancy and rapidly after parturition; during the 1 st week post partum the prolactin content was $400 \%$ higher than in the unmated female, and remained high, though falling gradually, throughout lactation. It is probable, therefore, that the coarse-granuled erythrosinophil cells produce prolactin (and correspond to the eta cells of Herlant, 1964) and the fine-granuled yellow cells growth hormone (alpha cells of Herlant, 1964). The staining reactions of these cell types in the rabbit thus resemble those in many other mammals (see Racadot, 1962). The increase in numbers and activity of the cells staining with orange G, previously reported by Gepts (1954) and confirmed in the present work, is compatible with the suggestion that they produce growth hormone. It is known that the co-operative action of a complex of hormones, of which growth hormone is one, controls the initiation and the maintenance of lactation in several species (see Cowie \& Folley, 1961; Moon, 1965).

The nature of the intra-nuclear bodies is obscure. Nuclear inclusions have been observed in cells of the pars distalis and many other organs in several 
species. The origin and significance of such structures is a matter of debate (see reviews by Serber, 1961; Bern, Nishioka \& Hagadorn, 1962). Serber (1961) found nuclear inclusions in the basiphil gonadotrophs of the hypophysis of the gonad-deficient hamster but not in normal hamsters. She concluded that the inclusions developed as invaginations from the cytoplasm into the nucleus and that they were associated with heightened secretory activity of the gonadotrophic cells. The intra-nuclear bodies observed by us in the erythrosinophil cells of the rabbit may be related to the rate of secretion of prolactin, since the incidence of these bodies is highest in early lactation, when the production of prolactin is proceeding most vigorously. Electron microscopic studies now in progress may answer this question.

\section{ACKNOWLEDGMENTS}

We are grateful to the Medical Research Council for a personal grant to one of us (M.A.). We thank Miss P. Rackham for technical assistance and Miss G. Cox for the photographs.

\section{REFERENCES}

Allanson, M., Foster, C. L. \& Menzies, G. (1957) Fixation of the rabbit pituitary gland. Nature, Lond. 180, 766.

Allanson, M., Foster, C. L. \& Menzies, G. (1959) Some observations on the cytology of the adenohypophysis of the non-parous female rabbit. $Q . \mathcal{F l}$ microsc. Sci. 100, 463.

Bern, H. A., Nishioka, R. S. \& Hagadorn, I. R. (1962). Neurosecretory granules and the organelles of neurosecretory cells. Mem. Soc. Endocr. No. 12, 21.

Bugnon, G. (1963) Les types cellulaires de la pars distalis de l'adéno-hypophyse chez le porc, leurs modifications dans divers états endocriniens: castration, gestation, lactation. Archs Anat. Histol. Embryol. 47, 397.

Cleveland, R. \& Wolfe, J. M. (1932) A differential stain for the anterior lobe of the hypophysis. Anat. Rec. 51, 409.

Cowie, A. T. \& Folley, S. J. (1961) The mammary gland and lactation. Sex and Internal Secretions, 3rd edn. Ed. W. C. Young. Baillière, Tindall \& Cox, London.

Dawson, A. B. (1946) Some evidences of specific secretory activity of the anterior pituitary gland of the cat. Am. F. Anat. 78, 347.

Foster, C. L. (1963) Post-coital cytological changes in the adenohypophysis of the non-parous rabbit. J. Endocr. 27, 293.

Foster, G. L., Young, B. A., Allanson, M. \& Cameron, E. (1965) Nuclear inclusions in the adenohypophysis of the rabbit. 7. Endocr. 33, 159.

Friedgood, H. B. \& Dawson, A. B. (1938) Cytologic evidence of the gonadotropic activity of the rabbit's anterior hypophysis. Endocrinology, 22, 674.

Gepts, W. (1954) Etude morphologique de l'hypophyse de la lapine au cours du post-partum. C.r. Séanc. Soc. Biol. 148, 189.

Herlant, M. (1960) Étude critique de deux techniques nouvelles destinées à mettre en évidence les différentes catégories cellulaires présentes dans la glande pituitaire. Bull. Microsc. appl. $10,37$.

Herlant, M. (1964) The cells of the adenohypophysis and their functional significance. Int. Rev. Cytol. 17, 299.

Herlant, M. (1965) Present state of knowledge concerning the cytology of the anterior lobe of the hypophysis. Proc. 2nd int. Congr. Endocrinology, London, 1964. Exerpta Medica Foundation, 83, 468.

Meites, J. \& Turner, G. W. (1942) Studies concerning the mechanism controlling the initiation of lactation at parturition. iv. Influence of suckling on the lactogen content of the pituitary of post partum rabbits. Endocrinology, 31, 340 .

Moon, R. C. (1965) Mammary growth in rats treated with somatotropin during pregnancy and/or lactation. Proc. Soc. exp. Biol. Med. 118, 181.

Pasteels, J.-L. (1963) Recherches morphologiques et expérimentales sur la sécrétion de prolactine. Archs Biol. 74, 439. 
Pasteels, J.-L. \& Herlant, M. (1962) Notions nouvelles sur la cytologie de l'antéhypophyse chez le rat. Z. Zellforsch. 56, 20.

Pearse, A. G. E. (1951) Application of cytochemistry to the localization of gonadotrophin in the pituitary. 7. Endocr. 7, 48.

Pearse, A. G. E. (1952) Cytochemical localization of the protein hormones of the anterior hypophysis. Ciba Fdn Colloq. Endocr. 4, 1.

RACADOT, J. (1962) Les types cellulaires du lobe antérieur de l'hypophyse des mammifères. Biologie Méd. 51, 166.

RACADOT, J. (1963) Modifications cytologiques du lobe antérieur de l'hypophyse de la brebis au cours du post-partum. C.r. Séanc. Soc. Biol. 47, 729.

SERBER, B. J. (1961) Large nuclear inclusions in pituitary gland basophils of the golden hamster. Anat. Rec. 139, 345. 